\title{
Performance Assessment of Different Solar Energy Technologies Based on Energy and Exergy Analyses Method: A Review
}

\author{
Muhammad Jamilu Ya' ${ }^{1,}$ ", Usman Aminu ${ }^{2}$, Mohammed Abdullahi Gele ${ }^{3}$, Yerima Yusuf Ali ${ }^{4}$, \\ Abdulkarim Mika'il Alhaji ${ }^{5}$ \\ ${ }^{1}$ Mechanical Engineering Department, Bayero University, Kano, Nigeria \\ ${ }^{2}$ Mechanical Engineering Department, Nuhu Bamalli Polytechnic, Zaria, Nigeria \\ ${ }^{3}$ Sokoto Energy Research Centre, Services Unit, Sokoto, Nigeria \\ ${ }^{4}$ Mechanical Engineering Department, Usman Danfodiyo University, Sokoto, Nigeria \\ ${ }^{5}$ Department of Physics, Federal University, Wukari, Nigeria

\section{Email address:} \\ jamiluunguwauku@gmail.com (M. J. Ya'u) \\ ${ }^{*}$ Corresponding author

\section{To cite this article:} \\ Muhammad Jamilu Ya'u, Usman Aminu, Mohammed Abdullahi Gele, Yerima Yusuf Ali, Abdulkarim Mika'il Alhaji. Performance \\ Assessment of Different Solar Energy Technologies Based on Energy and Exergy Analyses Method: A Review. International Journal of \\ Sustainable Development Research. Vol. 3, No. 6, 2017, pp. 63-76. doi: 10.11648/j.ijsdr.20170306.12
}

Received: September 20, 2017; Accepted: November 6, 2017; Published: November 30, 2017

\begin{abstract}
Renewable energy system usually refers to as an environmentally friendly energy system and most reliable and cost efficient one. Solar energy system is among the renewable energy system sourcing from sun that is freely available in nature. The utilization of renewable energy offers a wide range of exceptional benefits of human life, therefore its necessity for researchers to find ways of increasing the performance of the system in order to satisfy the human needs. In this work, a comprehensive review on performance assessment of different solar energy technologies using energy and exergy analysis approaches was carried out, and some important conclusions were drawn out. Some on the conclusions are energy efficiency for all the solar energy systems have been found to be greater than that of exergy efficiency and exergy analysis method is a very useful tool, especially on performance evaluation of solar energy systems.
\end{abstract}

Keywords: Exergy, Solar Photovoltaic, Solar Air Heater, Solar Cooker

\section{Introduction}

Renewable energy sources have found its way in the global energy market in a major way, thanks to the increasing conventional fuel prices, environmental degradation caused by the burning of fossil fuels. Energy consumption is one of the most reliable indicators of development and quality of line in a country. Electric power supply is one of the most essential factors for social, economic as well as industrial development. Yet, in Sub-Saharan Africa only $28 \%$ of the population has access to electricity [1]. This situation results in great difficulties to meet basic people needs (e.g. health and education) and impedes national development [2]. Human beings rely on the conventional sources of energy for their daily needs but the depleting and hazardous nature of this energy prompt the world towards development utilization of renewable energy sources such as solar, wind, biomass, tides, geothermal and hydropower.

Renewable energy sources involve the harnessing of natural energy flows or the tapping of natural stocks of energy whose rates of replenishment are comparable to or greater than the human use rates (such as ocean thermal gradients, biomass, and hydropower reservoirs) [3]. The World Commission on Environment and Development (WCED) called for renewable energy resources as the foundation of the global energy structure during the $21 \mathrm{st}$ century [4]. Energy is an essential and integral ingredient for socio-economic and technological development of a nation 
[5]. Energy is needed in theprovision of services, which are the desired and useful products and processes, such as for lighting, processing of engineering materials, and production of equipment and tools. Other areas are provision of airconditioned indoor climate, refrigerated storage, transportation and appropriate temperatures for domestic cooking and industrial cottage applications.

Solar energy is also one of the common renewable energy sources in the world. This energy is taken from the sun in the form of solar radiation. Solar energy being transmitted from the sun through space to earth by electromagnetic radiation must be converted to heat before it can be used in a practical heating or cooling system. Since solar energy is relatively dilute when it reaches the earth, the size of a system used to convert it to heat on a practical scale must be relatively large. Solar energy collectors, the devices used to convert the suns radiation to heat, usually consist of a surface that efficiently absorbs radiation and converts this incident flux to heat which raises the temperature of the absorbing material. A part of this energy is then removed from the absorbing surface by means of heat transfer fluid that may either be liquid or gaseous [6].

Energy analysis is concerned only with quantity of energy use and efficiency of energy processes. The energy analysis alone does not encounter the internal losses. It cannot be a sufficient criterion for the performance evaluation.

An exergy analysis is a useful method to complement not to replace the energy analysis. Exergy is the maximum work potential which can be obtained from energy [7]. Exergy analysis is recognized by many engineers to be a powerful tool for the evaluation of the thermodynamics and economic performance of system in general [8]. Exergy analysis yields useful results because it deals with irreversibility minimization or maximum exergy delivery. The popularity of the exergy analysis method has grown consequently and is still growing [9].

An extensive review performance assessment of different renewable energy systems has been done based on energy and exergy analysis method. The work has been divided into three viz:

I. Solar photovoltaic systems

II. Solar heating systems: -It has been classified in two different categories as below:

a) Solar air heater

b) Solar water heater

III. Solar cookers

\section{Performance Assessment of Different Solar Energy Technology}

Solar energy technologies are used to harness solar irradiance for many applications, these includes solar photovoltaic for electricity generations and solar heating systems like solar water heater which used water as a heating fluid, solar air heater where air is used as a heating fluid and solar cooker for heating, drying and cooking applications.
The performance assessment of these technologies is of different methods/approaches, in this paper the energy and exergy analyses are adopted.

\subsection{Solar Photovoltaic Systems}

Solar energy reaching the earth surface can be harnessed directly in two ways, firstly, by converting directly into electricity by the means of solar photovoltaic modules and secondly, by heating the medium by means of solar collectors for low temperature heating applications.

\subsubsection{Energy Analysis}

The actual output of the solar photovoltaic module can be expressed in the equation given below:

$$
Q_{0}=I_{m} V_{m}
$$

Where $I_{m}$ is the current corresponding to maximum power point (measured in Amphere) and $\mathrm{V}_{\mathrm{m}}$ is the voltage corresponding to maximum power point (measured in Volt).

And, the energy efficiency of solar photovoltaic module is defined by Pandey [10] as

$$
\eta=\frac{V_{O C} I_{S C}}{I_{S} A}
$$

Where $V_{o c}$ is an open circuit voltage $(V), I_{s c}$ is a short circuit current $(A), I_{s}$ is a solar radiation intensity $\left(\mathrm{W} / \mathrm{m}^{2}\right)$ and $A$ is surface area of the collector $\left(\mathrm{m}^{2}\right)$.

\subsubsection{Exergy Analysis}

The exergy of solar radiation or the input exergy is given by the equation

$$
E_{x_{i n}}=\left[1-\frac{T_{a}}{T_{S}}\right] I_{S} A
$$

Where $T_{a}$ is the ambient temperature and $T_{s}$ is the temperature of fluid in the module.

The exergy output of solar photovoltaic systems is

$$
E_{x_{\text {out }}}=E_{x_{\text {elec }}}+I^{\prime}
$$

Where $I^{\prime}=E_{x_{\text {therm }}}+E_{x_{d}}$

The exergy output of solar photovoltaic systems can be given as

$$
E_{x_{P V}}=V_{m} I_{m}-\left[1-\frac{T_{a}}{T_{c e l l}}\right] h_{c a} A\left(T_{c e l l}-T_{a}\right)
$$

Where $T_{\text {cell }}$ is a temperature of the cell and $h_{c a}$ is the heat transfer coefficient which is given as $h_{c a}=5.7+3.8 v$ and $\mathrm{v}$ is wind speed.

The power conversion efficiency can be defined as the ratio of actual electrical output to the input energy on the solar photovoltaic surface and is given as

$$
\eta_{p c e}=\frac{V_{m} I_{m}}{I_{S} A}
$$

The exergetic efficiency of a solar photovoltaic is normally given by the equation 


$$
\Psi=\frac{E_{x_{P V}}}{E_{x_{i n}}}
$$

\subsubsection{Review on Energy and Exergy Analysis of Solar Photovoltaic System}

Sahin et al. [11] worked on thermodynamic characteristics of the solar photovoltaic (PV) cells using exergy analysis. The authors analyzed the PV cells on the basis of the energy and exergy efficiencies, the energy efficiency was found to be varying between $7-12 \%$ during the day while, the exergy efficiency was found to be varying between $2-8 \%$. Hepbasli et. al. [12] carried-out a comprehensive review on exergy analysis of several solar energy systems especially the photovoltaic/thermal (PV/T) systems and the expressions as given by Fujisawa and Tani [13] and Saitoh et al. [14] were found to be similar to those given by Hepbasli et al. [12].

Joshi et al. [15] performed energy and exergy analysis of a photovoltaic (PV) and photovoltaic/thermal (PV/T) system for the New Delhi, India. The authors found that in the case of $\mathrm{PV} / \mathrm{T}$, the energy efficiency varies between $33-45 \%$, whereas the exergy efficiency varies between $11-16 \%$. And for PV alone, the exergy efficiency was found to be varying in the range of $8-14 \%$ for a typical set of operating parameters. Sarhaddi et al. [16] analyzed the solar photovoltaic thermal (PV/T) air collector using exergetic method. The authors used an improved electrical model for the estimation of the electrical parameters of a PV/T air collector and then in terms of design and climatic parameters a modified equation for the exergy efficiency of a PV/T air collector is derived. For calculating thermal and electrical parameters of a PV/T air collector had also been developed. Numerical simulation results and modified exergy efficiency obtained in their work showed the good agreement with the experimental measurements noted in the previous literature. For a sample climatic, operating and design parameters, the thermal efficiency, electrical efficiency, overall energy efficiency and exergy efficiency of PV/T air collector were found to be $17.18 \%, 10.01 \%, 45 \%$ and $10.75 \%$ respectively. Hosseini et. al. [17] performed energy and exergy analysis of hybrid solar-fuel cell combined heat and power system. The energy and exergy efficiency of the photovoltaic system were found $17 \%$ and $18.3 \%$ respectively. However, the total (PV and Fuel cell combined) energy and exergy efficiencies were found to be $55.7 \%$ and $49 \%$ respectively.

Tiwari et al. [18] carried out the literature review on thermal modeling of photovoltaic (PV) modules and their applications. In the review article different applications of photovoltaic module based on electrical and thermal output has been covered. Moreover, the authors covered the detailed description and thermal model of photovoltaic and hybrid photovoltaic/thermal systems, using air and water as the working fluid. The numerical modeling and analysis of thermal and electrical output of photovoltaic and hybrid photovoltaic/thermal in terms of an overall thermal energy and exergy has been carried out in this study. They found that the photovoltaic/thermal (PV/T) modules were very promising devices and there exists a lot of scope to further improve the performances after performing an extensive review. A review on performance evaluation of photovoltaic (PV) and photovoltaic/thermal (PV/T) systems based on electrical as well as thermal output e.g., electrical, thermal, energy, and exergy efficiency was done by Joshi et al. [19]. Applications of photovoltaic systems were divided according to their use, i.e., electricity production and thermal applications. A case study for PV and PV/T system based on exergy analysis was also presented. From the thorough literature review, they found that the exergy efficiency of $\mathrm{PV} / \mathrm{T}$ systems is higher than those of PV alone system as the $\mathrm{PV} / \mathrm{T}$ systems gives useful thermal output apart from electricity. Also, it has been observed from the study that electrical as well as thermal efficiencies can be increased by using reflecting surfaces because by using reflector more incident radiations can be used. The thermal efficiency of $\mathrm{PV} / \mathrm{T}$ water collector has been found to be more than that of $\mathrm{PV} / \mathrm{T}$ air collector which is an obvious case as the density of water is higher than that of air.

Vats and Tiwari [20] studied on the performance study of a building integrated semi-transparent photovoltaic/thermal system integrated on the roof of a room based on energy and exergy analysis. Six different types of solar PV modules viz. mono-crystalline Silicon (m-Si), multi-crystalline Silicon (mc-Si), amorphous silicon (a-Si), Cadmium-Te, CIGS and hetro-junction with intrinsic thin layer (HIT) have been used for comparative performance evaluation. They found that as the cell temperature increases the exergy efficiency decreases and the maximum annual electrical energy produced by HIT was found to be $810 \mathrm{kWh}$, and suggested that this module suitable for generating electricity. However, maximum annual thermal energy produced by a-Si was found to be 464 $\mathrm{kWh}$ and it was also found that to be suitable for space heating applications while the efficiency was found to be $16.0 \%$ for HIT and $6.0 \%$ for a-Si respectively.

\subsection{Solar Heating Systems}

The solar heating systems are systems which convert solar energy collected from sun into heat with the aid of collectors for useful applications. This section presents the performance assessment on different solar heating systems, these includes, solar air heater and solar water heater for useful applications.

\subsubsection{Solar Air Heater}

Solar air heaters are devices which use air as the circulating fluid for useful applications such as air heating, space air- conditioning, and crop drying applications by directly using the solar energy.

\section{Energy Analysis}

The solar energy incident on the collector surface is given by [21]

$$
Q_{c}=I_{s} A
$$

Where $\mathrm{A}$ is the area of collector exposed to the sun light and $I_{s}$ is the intensity of solar radiation at a particular location. 
The energy collected from the collector can be written as [21]

$$
Q_{u}=\alpha \tau Q_{c}
$$

Where $\alpha$ is the absorptance of glass and $\tau$ is the transmittance of outer surface of the collector.

The useful energy transmitted into the collector is absorbed by the circulating fluid/air, and can be written as below [21]

$$
Q_{f}=\dot{m}_{f} C_{p, f} \Delta T
$$

Where $\mathrm{C}_{\mathrm{p}, \mathrm{f}}$ is a specific heat capacity of the circulating fluid, $\dot{m}_{f}$ is a mass flow rate of the circulating air/fluid, $\Delta \mathrm{T}$ is the temperature difference and $\mathrm{Q}_{\mathrm{f}}$ is the heat absorbed by the fluid.

The energy efficiency of the system can be written as [22]

$$
\eta=\frac{Q_{f}}{Q_{c}}
$$

\section{Exergy Analysis}

Neglecting the changes in gravitational force, momentum and pressure the exergy balance equation for the solar air heater can be given as:

$$
\text { Exergy }=C_{p}\left[\left(T-T_{\infty}\right)-T_{\infty} \ln \left(T / T_{\infty}\right)\right]
$$

Exergy received by collector is given as

$$
E_{x_{c}}=Q_{c}\left[1-\left(T_{a} / T_{s}\right)\right]
$$

Exergy received by the fluid is given as

$$
E_{x_{f}}=m\left[\left(h_{0}-h_{i}\right)-T_{a}\left(S_{0}-S_{i}\right)\right]
$$

And the exergy efficiency of solar air heater is

$$
\Psi=\frac{E_{x_{f}}}{E_{x_{c}}}
$$

\section{Review on Energy and Exergy Analysis of Solar Air Heater}

It is very important for the end products to dry completely for domestic used and/or commercial applications to maintain the quality and nutrient values of the product for their safe storage. Thermal storage systems are refer to as sensible heat storage, latent heat storage and chemical energy storage are used to store thermal energy. The solar drier is an energy efficient option in the drying processes [23]. Use of forced convection solar driers seems to be an advantage compared to traditional methods and improves the quality of the product considerably [24]. The common sensible heat storage materials used to store sensible heat are water, sand, gravel bed, clay, concrete, etc. for different applications [25].

Recently, some solar systems researchers have worked on different feature of solar collector systems using various approaches. Kurtbas and Durmus [26] have studied the solar air heater for different heating purposes while, Luminosua and Farab [27] and Torres-Reyes et. al, [28] have studied the optimal thermal energy conversion and design of a flat plate solar collector using exergy analysis. Furtherover, Bakos et al [29], Kaushik et al. [30], and Tyagi et al [31] did the optimum design of a parabolic trough collector (PTC) and gave good results, especially, the concentration ratio (CR) of parabolic trough collector and the mass flow rate of the moving fluid.

Enibe [32] worked on the design, fabrication and performance evaluation of a passive solar powered air heating system based on exergy analysis. The system consists of a single-glazed flat plate solar collector integrated with a phase change material (PCM) heat storage system. The phase change material is prepared in modules, with the modules equal spacing across the absorber plate. The spaces between the module pairs serve as the air heating channels, the channels being connected to common air inlet and discharge headers. The experiments were carried out under the climatic conditions of Nsukka (Nigeria) in the daytime with no-load conditions where the ambient temperature varied in the range of $19-41^{\circ} \mathrm{C}$, and a daily global irradiation varied in the range of 4.9-19.9 $\mathrm{MJ} / \mathrm{m}^{2}$. Peak cumulative useful efficiency was found to be about $50 \%$ while peak temperature rise of the heated air was about $15^{\circ} \mathrm{C}$. The system has been found suitable for the use as a solar cabinet crop dryer for aromatic herbs, medicinal plants and other crops, which do not require direct exposure to sunlight.

Kurtbas and Durmus [26] designed a new type of solar air heater and evaluated it using exergetic analysis. They used five solar collectors with dimensions of $0.9 \times 0.4 \mathrm{~m}$ and were set to four different cases. They found that the efficiency of the collector increases with the increase of mass flow rate which is due to the increased heat transfer to the air flow. They suggested that the collector efficiency, the inlet and outlet temperature difference the air geometry and pressure loss etc are some of the more important parameters for evaluating the performance of a collector. Ajam et al. [33] worked on the optimization of the solar air heater based on the exergetic analysis. For this purpose, an integrated mathematical model of thermal and optical performance of the solar heater has been derived. The overall thermal loss coefficient and other heat transfer coefficients of the heater were assumed to be variable while deriving an equation for the exergy efficiency. After maximizing the exergy efficiency equation using MATLAB toolbox, the equation has been compared with the thermal efficiency of the heater, which ultimately results in an extraordinary increase of the exergy efficiency according to the optimized parameters. They also concluded that the exergy analysis was a better method for design, development and optimization of solar air heaters due to the fact that exergy efficiency is a proportion to common quantities in solar engineering such as thermal efficiency, temperature, pressure drop, mass flow rate of fluid and others etc.

The thermal performance of asolar air heater having its flow channel packed with Raschig rings based on the energy and exergy analyses was experimentally investigated by Ozturk and Demirel [34]. Average daily net energy and 
exergy efficiencies were found to be 17.51 and $0.91 \%$, respectively. Also, the energy and exergy efficiencies of the packed-bed solar air heater increased as the outlet temperature of heat transfer fluid increased. MacPhee and Dancer [35] worked on thermodynamic analyses of the process of charging of an encapsulated ice thermal energy storage device (ITES) through heat transfer. The energy efficiencies are found to be more than $99 \%$, whereas the thermal energy efficiencies are found to vary between $40 \%$ and $93 \%$ for viable charging times. The results confirm the fact that energy analyses, and even thermal exergy analyses, may lead to some unrealistic efficiency values.

Kurtbas and Turgut [36] investigated the solar air heater with free and fixed fins using exergy analysis. In this study each of the fins with rectangular shape was having two different surface areas and located on the absorber surface in free and fixed manners. In the first type, the fins were located on the absorber surface in away that the fins are able to move freely, while in the second type model fins were fixed to the absorber surface. The absorber surface area was $1.64 \mathrm{~m}^{2}$ while the fixed and free fins with 8 and 32 items were having surface areas 0.048 and $0.012 \mathrm{~m}^{2}$ respectively. Therefore, the total fin area in the absorber surface was equal to $0.384 \mathrm{~m}^{2}$. They found that the fins located in flow area increases the heat transfer coefficient and output temperature of air due to which collector efficiency increases too. Also, they found that there exists a reverse relationship between exergy loss ratio and collector efficiency as well as temperature difference of the fluid. Thus, if there is increase in the pressure drop, both heat transfer and exergy loss were also found to be enhanced, while it has been observed that the exergy loss ratio was affected less because heater has very little pressure drop. Esen [37] carried-out the energy and exergy analysis of a novel flat plate solar air heater (SAH) with and without obstacles. In this study, the experiment was carried out by varying the flow rate of air at different levels of absorbing plates inthe flow channel duct. The schematic view of the double flow SAH system and front view of the collector are shown in Figure 1(a) and (b) respectively. The measured parameters were solar radiation and temperatures at different state of points such as inlet, outlet, at the absorbing plate and the ambient. It had been observed that, the optimal value of efficiency was in the middle level of absorbing plate in flow channel duct for all the operating conditions and it was also found that the double-flow collector supplied with obstacles $(60.97 \%$, for $0.025 \mathrm{~kg} / \mathrm{s}$ and State II) were better than that of without obstacles $(25.65 \%$, for $0.015 \mathrm{~kg} / \mathrm{s}$ and State I).

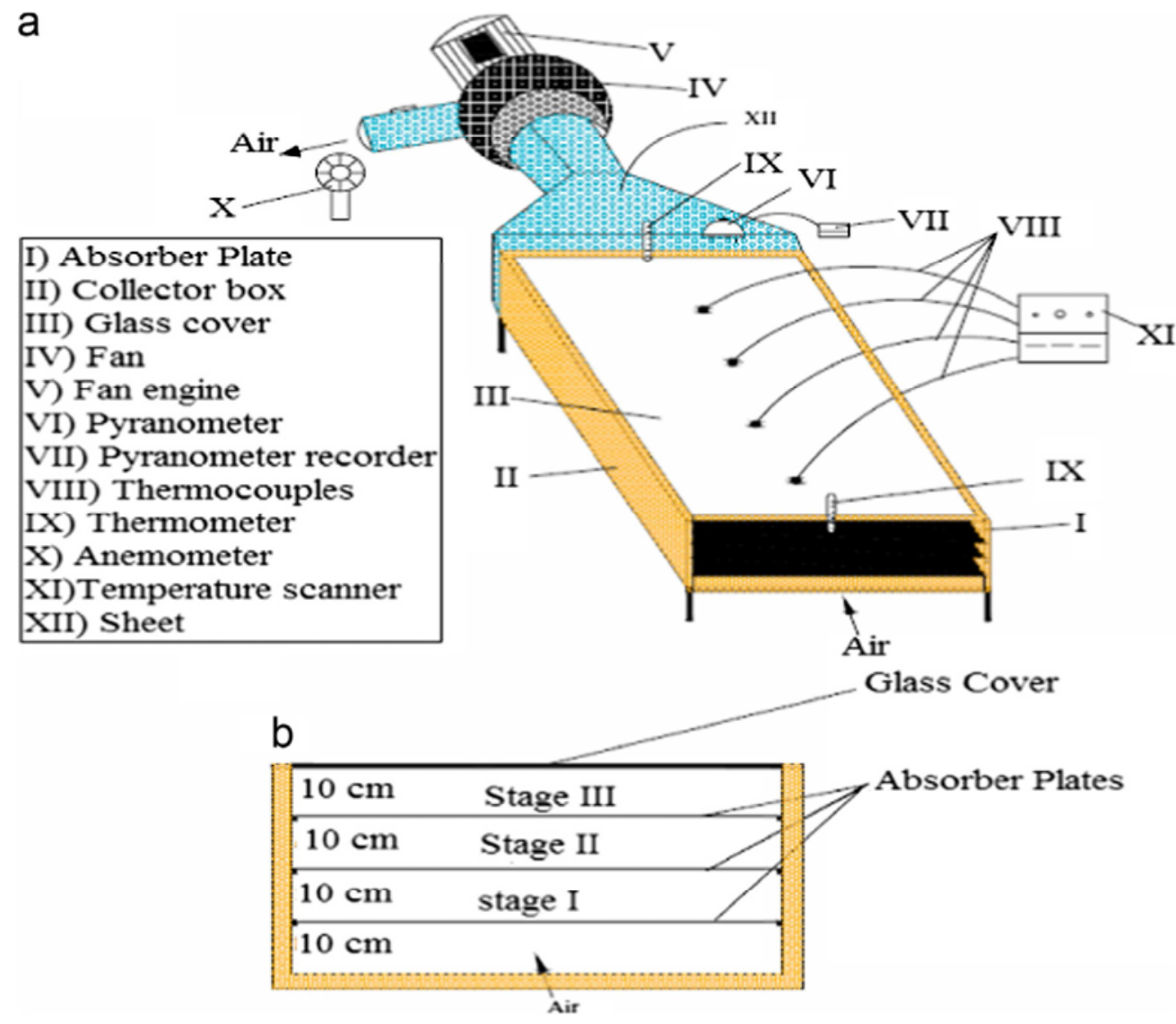

Figure 1. Schematic assembly of the (a) SAH system and (b) front view of the collector.

Ucar and Inalli [38] worked on the solar air collectors with passive augmentation techniques using exergetic analysis. In order to provide better heat transfer surfaces suitable for the passive heat transfer augmentation techniques different shape and arrangement of absorber surfaces of the collectors were reorganized. The performance of this solar air collectors with staggered absorber sheets and attached fins on absorber surface were analyzed and tested. The result revealed that the 
efficiency of solar collector has been increased approximately $10 \%$ to $30 \%$ as compared with the conventional solar collector using the passive techniques. In conventional solar air heater, only a little part of solar energy absorbed by the collector can be used therefore the performance of the conventional solar air heater was found to be least. Koca et al. [39] investigated the flat-plate solar collector with phase change material (PCM) using energy and exergy analysis, $\mathrm{CaCl}_{2} \cdot 6 \mathrm{H}_{2} \mathrm{O}$ has been used asphase change material in thermal energy storage (TES) system. Solar energy collection and storage has been combined in single designed collector unit. Phase Change Material was stored in a storage tank, which was located under the collector. For transferring heat from collector to PCM a special heat transfer fluid was used. The experiments were carried out for 3 different days in the month of October. From the measured data, calculations were made and the result showed that stored and instantaneous solar radiation show bell-shaped variation during all experimental days. Also, a significant difference between energy and exergy efficiencies had been reported and the energetic efficiency was always higher than that of exergetic efficiency. From the obtained experimental data and calculations it has been found that the exergy efficiencies of latent heat storage systems with PCM are very low.

Gupta and Kaushik [40] presented a comparative study of various types of artificial roughness geometries in the absorber plate of solar air heater duct and their characteristics based on energy, effective and exergy efficiencies. The performance evaluation for some selected artificial roughness geometries in the absorber plate of solar air heater duct in terms of energy efficiency, effective energy efficiency and exergy efficiency has been carried out at various values of Reynolds number (Re). In this study the correlations for heat transfer and coefficient of friction developed by respective investigators have been used to calculate efficiencies. From the study it has been found that the artificial roughness on absorber surface is the better option in the enhancement of the efficiencies in comparison to smooth surface. The energy efficiency was found to be increased in the following manner: smooth surface, circular ribs, V-shaped ribs, wedge shaped rib, expanded metal mesh, rib-grooved, and chamfered rib-groove. The effective efficiency also found to be following the same trend of variation among various considered geometries however trend was reversed at very high Reynolds number. The exergy efficiency based criteria also follows the same pattern; but the trend was reversed at relatively lower value of Reynolds number and for higher range of Reynolds number the exergy efficiency approaches zero or may be negative. Ozgen et al. [41] had worked on a device for inserting an absorbing plate made of aluminumcans into the double-pass channel in a flat-plate solar air heater. In this experimental study, three different absorber plates had been designed andtested. In the first type (Type I), cans had been staggered as zigzag on absorber plate, and in Type II they were arranged in order, while in Type III a flat plate was without cans. Experiments were performed at air mass flow rates of $0.03 \mathrm{~kg} / \mathrm{s}$ and $0.05 \mathrm{~kg} / \mathrm{s}$. From the experiments it has been found that the double-flow type of the solar air heater with aluminum cans has been introduced for increasing the heat transfer area has the improved thermal efficiency. Because of the double heat transfer area in double-flow systems, the performance of double-flow type solar air heater, in which air was flowing simultaneously over and under absorbing plate, isfound to be more efficient than that of the devices with one flow channel over or under the absorbing plate.

Farahat et al. [42] worked on the exergetic optimization of flat plate solarcollector, in this study a simulation program has been developed for the thermal and exergetic calculations. A detailed energy and exergy analysis was carried out for evaluating the thermal and optical performance, exergy flows and losses as well as exergetic efficiency for a typical flat plate solar collector under given operating conditions. The optical efficiency has a great effect on the exergy efficiency. By using the flat plate solar collectors with optical concentrators, the optical efficiency increases. It was found that the energy efficiency increases without extremism points with operating parameters. The absence of such maximum points has created difficulties in the design of flat plate solar collectors. However, the exergy efficiency presents points of local maxima and a point of global maximum. The exergy efficiency was found to be decreasing rapidly with increasing nature of ambienttemperature and the wind speed. Akbulut and Durmuş [43] had worked on energy and exergy analyses of the thinlayer drying process of mulberry via forced solar dryer. The drying experiments were carried out at five different mass flow rate varied between $0.014 \mathrm{~kg} / \mathrm{s}$ and 0.036 $\mathrm{kg} / \mathrm{s}$. The effects of drying time and inlet air velocity on energy and exergy were evaluated. The values of exergy loss were found to be as $10.82 \mathrm{~W}, 6.41 \mathrm{~W}, 4.92 \mathrm{~W}, 4.06 \mathrm{~W}$ and $2.65 \mathrm{~W}$ with the drying mass flow rate varied in the range, mentioned above. However, the values of energy utilization ratio were found to be as $55.2 \%, 32.19 \%, 29.2 \%, 21.5 \%$ and $20.5 \%$ for the above said five different drying mass flow rates. From the study it was found that the exergy loss decreases with the increase in the mass flow rate of the drying air. The maximum exergy losses occurred for $0.014 \mathrm{~kg} / \mathrm{s}$ mass flow rate. After the study of thermal performance of solar dryer it had been suggested that, in order to decrease the energy utilization and exergy losses: order, structure, and moisture content of the products on the drying chamber should be taken into consideration. Also it is necessary to show the variations of exergy withdrying time in order to get when and where the maximum and minimum values of theexergy losses occur during the drying process.

Akpinar and Kocyigit [44] designed, fabricated and experimentallyinvestigated a new type of solar air heater with and without obstacles. The schematic diagram of the experimental setup is shown in Figure 2 below. The experiments were carried out at two different air mass flow rates of 0.0074 and $0.0052 \mathrm{~kg} / \mathrm{s}$. It was found that the efficiency of the solar air collectors depends on different 
parameters such as solar radiation, surface geometry of the collectors and extension of the air flow line. The energy efficiency were found to be varied between $20 \%$ and $82 \%$ while those of exergy efficiency changed from $8.32 \%$ to $44.00 \%$ at the above said mass flow rates. The highest efficiency was found to be for the solar airheater (SAH) with absorbent plate in flow channel duct for all operating conditions, whereas the lowest values were obtained for the solar air heater without obstacles. Also the efficiency of the collector has been found to be increasing function of mass flow rate. This shows that the exergy loss of the system decreased due to the increase in thecollector efficiency. Reverse relationship between dimensionless exergy loss and heat transfer were also found in the study. The deciding parameters in order to decrease the exergy loss were the collector efficiency, temperature difference of the air. New relations were proposed to evaluate of the energy and exergy analysis of solar air heater. It is concluded that the proposed procedure can be successfully employed for predicting the solar air heater performance.

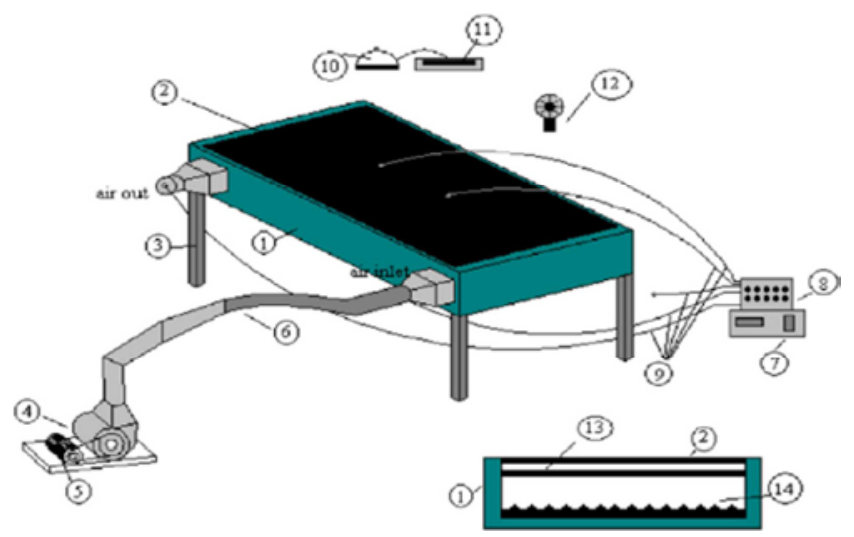

Figure 2. Schematic view of experimental setup. (1) Collector box, (2) glass cover, (3) foot, (4) fan, (5) fan engine,(6) connection pipe, (7) channel selector, (8) digital thermometer, (9) thermocouples, (10) pyranometer, (11) pyranometer recorder, (12) anemometer, (13) absorber plate (copper plate that has been painted black) and (14) absorber plate with obstacles.

Alta et al [45] investigated the energy and exergy efficiency of three different types of solar air heaters, two having fins and one without fins besides one heaters with fins has single glass cover while the other two have double glass cover. The energy and exergy output rates of the solar air heaters were evaluated at different air flow rates viz. 25, 50 and $100 \mathrm{~m}^{2} / \mathrm{m}^{2} \mathrm{~h}$, tilt angle at $0^{\circ}, 15^{\circ}$ and $30^{\circ}$ and temperature conditions versus time. They found that the heaters with double glass covers andfins are more effective and the difference between the input and output air temperature is higher than that of the other cases. It was also found that the lower airflow rates will be beneficial in applications where higher temperature differences are more important. Besides it has also been observed that using more transparent cover and fins increases the values of temperature differences. While transparent coverdecreases convection heat losses, fins obtain more heat because of an increase in the heating time by circulating air inside. Prommas et al. [46] worked on the energy and exergy analyses in drying process of porous media using hot air. The main objectives of the study were as follows: (a) exergy input and the distributions of the exergy losses of the different drying operations (b) the exergy losses of two operations porous packed bed and (c) the effect of operating parameters on exergy losses. From the study it was found that as the drying time increases, the exergy efficiency of the drying chamber also increases which is due to the fact that as the drying time increases the availableenergy in the drying chamber also increases. They also presented the effect of theother particle size on the drying time as well as the exergy efficiency of the drying system. Furthermore, it was found that the exergy efficiencies of C-bed were higher than of the F-bed about $10 \%$ after $60 \mathrm{~min}$ of drying time with parallel to the end of drying process.

Panwar et al. [47] did thorough review on energy and exergy analyses of solar drying systems and suggested that for utilizing low grade energy to dry agricultural produces solar drying is the promising option. In their study they found that the exergy efficiency is actual efficiency of the process due to irreversibility associated with the system. Therefore it can be said that exergy analysis is a tool to access the efficient usage of solar energy. It is the property of the system, which gives the maximum power that can be obtained from the system when it is brought toa thermodynamic equilibrium state from a reference state. The energy used in drying of agricultural and industrial produce is significant and, therefore, represents an often reducible element of process cost. Saidur et al. [48] reviewed the literature on exergy analysis of solar energy applications viz. solar photovoltaic, solar pond, solar air conditioning etc. From their study they found that the thermal efficiency is not sufficient to choose the desired system therefore it is necessary to apply the concept of exergy for specific design ofthe systems. The highest exergy destruction was observed in solar collectors in most of the solar heating devices and solar air conditioning systems. Increasing the mass flow rate leads to an increment in exergetic efficiency in photovoltaic thermalsystems. Exergy efficiency of solar systems is highly dependent on the daily solar radiation and radiation intensity.

\subsubsection{Solar Water Heater}

Solar water heaters are systems used to get hot water from solar irradiance and it has many useful applications such as domestic, industrial and commercial applications. It consists of a collector, for collecting solar radiation from sun, and insulated storage tank, to store hot water.

Water is one of the most essential needs in life, therefore it is good for the researchers to find a way of using solar radiation to heat the water for some application, and hence solar water heater was design to satisfy the human needs. The solar water heaters that are available in the market areflat plate collector (FPC), evacuated tube collector (ETC) and compound parabolic collectors (CPC).

\section{Energy Analysis}

The useful energy of solar water heater is given by the equation below 


$$
Q_{w}=Q_{c}-\left(Q_{b}+Q_{l}\right)
$$

Where Energy stored in a body $=Q_{b}=m_{b} C_{b}\left(T_{f b}-\right.$ $\left.T_{i b}\right)$ and Energy lost $=Q_{l}=U_{t}\left(T_{m, s t}-T_{a}\right) \quad$ but Mean temperature of the system $=T_{m, s t}$ and $\mathrm{U}_{\mathrm{t}}$ is the rate of total heat loss coefficient. [49]

The useful energy gained by water in the tank is given by

$$
Q_{w}=m_{w} C_{p, w}\left(T_{f}-T_{i}\right)
$$

The energy efficiency of the solar water heating system can be written as [56]

$$
\eta=\frac{Q_{w}}{I_{S} A}
$$

\section{Exergy Anaysis}

The exergy gained by the collector is given by

$$
E_{x_{c}}=I_{s} A\left[1-\left(T / T_{s}\right)\right]
$$

The exergy received by the fluid is given as

$$
E_{x_{f}}=m\left[\left(h_{0}-h_{i}\right)-T\left(S_{0}-S_{i}\right)\right]
$$

And the exergy efficiency of solar air heater is

$$
\Psi=\frac{E_{x_{f}}}{E_{x_{c}}}
$$

\section{Review on Energy and Exergy Analysis of Solar Water Heater}

Xiaowu and Ben [50] worked on the performance evaluation of domestic scale solar water heater based on exergy analysis. From the study, the results show that the proper insulation of collector and storage barrel were important as exergy losses due to imperfectly thermal insulation in collector and exergy losses due to imperfectly thermal insulation in storage barrel cannot be avoided. The exergetic efficiency of domestic-scale water heater was determined to be small due to low quality of output energy and exergy losses storage barrel. Luminosu and Fara [27] obtained the optimal operation mode of flat plate collector using exergy analysis through simulation. In this study the exergy analysis of a flat-plate solar collector based on the assumption that temperature at inlet fluid is the same to environment temperature as remain constant has been developed. The statistical data for thesolar radiation of a given area was used and the optimal values for the characteristic quantities of the flat-plate solar collector had been found by developing the exergyanalysis for the selected model. Gunerhan and Hepbasli [51] performed the evaluation of solar water heating system based on exergy analysis. The experiments were carried out underthe climatic condition of Izmir province (Turkey). The main objective of the work wasto analyze the different components of the system such as flat plate solar collector, aheat exchanger (storage tank) and a circulating pump, and also to investigate theeffect of variation in water inlet temperature on exergy efficiency of different components and the overall system. The exergy efficiency on a product/fuel basis was found to be varying between 2.02 and $3.37 \%$ for the solar collector, 16 and $51.72 \%$ for the heat exchanger, 10 and $16.67 \%$ for the circulating pump, while for overall system it was found to be in the range of 3.27 to $4.39 \%$. Hayek et al. [52] investigated the performance evaluation of two different types of evacuated tube solar collectors viz. water-in-glass tubes and the heat-pipe designs under local weather conditions as encountered along the eastern coast of the Mediterranean Sea. The experiments were performed during the winter-like conditions (months of November to January) for a clear sky day of the months. Total 20 numbers of evacuated tubes along with a tank and a circulation system with measurement tools, was constructed and used for the experimental observation. The experimental study showed that the performance of ETC with heat pipe design was better than that of water-in-glass designs and their efficiency has been found to be almost 15 to $20 \%$ higher.

Ayompe et al. [53] worked on the performance evaluation of two different typesof solar water heaters flat plate collector (FPC) and heat pipe evacuated tube collector (ETC) in temperate climate of Dublin (Ireland). The energy analysis ondaily, monthly and yearly basis was carried out and the performance of the above-mentioned systems were compared. Total $1984 \mathrm{kWh}$ and $2056 \mathrm{kWh}$ of heat energy were collected by the $4 \mathrm{~m}^{2} \mathrm{FPC}$ and $3 \mathrm{~m}^{2}$ ETC systems respectively, for an annual solar radiation of $1087 \mathrm{kWh} / \mathrm{m}^{2}$. The annual average collector efficiencies were foundto be $46.1 \%$ and $60.7 \%$, while the system efficiencies were found to be $37.9 \%$ and $50.3 \%$ for the FPC and ETC respectively. Gang et al. [55] studied the compound parabolic concentrator (CPC)-type solar water heater with a U-pipe and investigated its performance in meeting higher temperature requirements. The experiments were carried out at Hefei in the eastern region of China in the month of December. Theyfound that these types of systems are not useful for higher temperature applications like heat-powered cooling, building heating, industrial heating, sea water desalination and so on. Hence in their work the compound parabolic concentrator (CPC)-type solar water heater with a U-pipe has been investigated. They found thatwhen the water temperature was heated from $26.9^{\circ} \mathrm{C}$ to $55,65,75,85$, and $95^{\circ} \mathrm{C}$, thermal efficiency was found to be decreasing function. In other words, the lower thermal efficiency has been found at $95^{\circ} \mathrm{C}$ and found to be above $49 \%$. The exergetic efficiency has been found to be increasing in nature i.e. highest efficiency was found to be at $55^{\circ} \mathrm{C}$ and found to always above $4.62 \%$.

Ceylan [49] developed a new temperature controlled solar water heater (TCSWH) and studied it based on energetic and exergetic analyses. Experiments have been carried out at 40, 45,50 and $55^{\circ} \mathrm{C}$ and the designed system was also compared with the thermo-siphon system. A detailed comparison between TCSWH and thermo-siphon system were performed by calculating stored energy, storage tank water temperatures, amount of water in the storage tank and systemefficiencies for both of the systems. The highest amount of water had 
been found tobe $108 \mathrm{~kg}$ by setting the control device at $40^{\circ} \mathrm{C}$. The average energetic efficiency was found to be $65 \%$ for the TCSWH and $60 \%$ for the thermo-siphon system respectively, thus, TCSWH was found to be better than that of thermosiphon system for the same set of operating parameters.

\subsection{Solar Cooker}

Solar cookers are the most promising devices since firewood used for coking causes deforestation, health hazard and other social and economic issues. Solar cookers use solar energy as a fuel which is intermittent in nature and available only in day time.

Solar cooker is classified into three classes as panel type solar cooker, box type solar cooker and paraboloid concentrating type solar cooker as shown Figure 3 below:

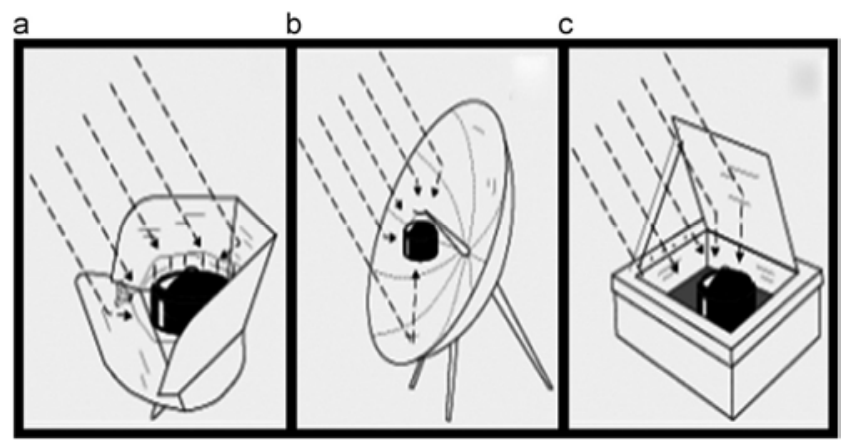

Figure 3. Types of solar cookers: (a) solar panel cooker; (b) solar parabolic cooker; and (c) solar box cooker.

\subsubsection{Energy Anaysis}

Energy input of the solar cooker is given by

$$
E_{i}=I_{s} A
$$

Where A is area of aperture of solar cookers Energy output of the solar cooker is given by

$$
E_{0}=\frac{m_{w} C_{p w}\left[\left(T_{w f}-T_{w i}\right)\right]}{\Delta t}
$$

Where $m_{w}$ is mass of water, $C_{p w}$ is specific heat of water, $\mathrm{T}_{\mathrm{wf}}$ is final temperature of water, $\mathrm{T}_{\mathrm{wi}}$ is initial temperature of water, $\Delta \mathrm{t}$ is time difference.

And the energy efficiency of solar cooker can be written as:

$$
\eta=\frac{E_{0}}{E_{i}}
$$

\subsubsection{Exergy Analysis}

The exergy input of solar cooker can be written as

$$
E_{x_{i}}=I_{s}\left[1+1 / 3\left(\frac{T_{a}}{T_{s}}\right)^{4}-4 / 3\left(\frac{T_{a}}{T_{s}}\right)\right] A_{s c}
$$

The exergy output of the solar cooker, when the temperature of the water increased from $T_{w i}$ to $T_{w f}$ is given as:

$$
E_{x_{0}}=\frac{m_{w} C_{p w}\left[\left(T_{w f}-T_{w i}\right)-T_{a} \ln \frac{T_{w f}}{T_{w i}}\right]}{\Delta t}
$$

The exergy efficiency of the solar cooker can be given as below:

$$
\Psi=\frac{E_{x_{f}}}{E_{x_{c}}}
$$

\subsubsection{Review on Energy and Exergy Analysis of Solar Cooker}

Recently, many authors have investigated methodologies for the evaluation and comparison of solar cookers [55]. Traditional methods of characterizing the performance of solar cookers are based on energy analysis as they are based on the first law of thermodynamics and provide information about the total quantity of energy without investigating the quality and the availability of energy [56]. The first study on energy and exergy efficiencies of solar cookers was conducted by Ozturk [57] in 2004. It was stressed in his article that there was large difference in energy and exergy output and efficiency because of changes in cooker configuration. It was also seen that the exergy analysis was more convenient than the energy analysis for predicting solar cooker efficiency. Inspired from the study of Ozturk [57], Petela [58] in 2005 carriedout the performance evaluation of a cylindrical trough shape solar cooker based onthe exergetic analysis. A comparative study on energy and exergy efficiency for boxtype and parabolic type solar cookers was done by Oztruk [57] under the climatic conditions of Turkey.

Nahar [59] designed, constructed and tested the performance of a novel solar cooker that does not require any tracking and its performance was compared with a hot-box type solar cooker. The overall efficiency of the novel solar cooker was foundto be $29.5 \%$. The performance evaluation ofthe box-type solar cooker with special consideration on the shape of lid of the utensils used was done by Gaur et al. [60]. The analysis revealed that the performance of a solar cooker could be improvedif a utensil with a concave shape lid is used instead of a plain lid providedwith the solar cookers. Buddhi et al. [61] analyzed the thermal performance of abox type solar cooker on the basis of first and second figure of merit with and without load respectively and the result shows that the second figure of merit depends on the quantity of water loaded in the solar cooker and emphasized that the test method should specify the amount of water to be taken.

Petela [59] studied the performance evaluation of simple parabolic type solarcooker (SPC) of the cylindrical trough shape using exergy analysis. The model allowed the theoretical estimation of the energy and exergy losses: unabsorbed insolation, convective and radiative heat transfers to the ambient. Besides, the exergy losses: the radiative irreversibilities on the surfacesand the irreversibility of the useful heat transferred to the boiling water. Detailed methodology for the exergy analysis of SPC and the distribution of the exergy losses had been presented in this study and he also explained the method of determining exergy loss on the radiating surface specifically, when the surface absorbs radiation fluxes at different temperatures. From the study it had been observed that for the enhancement of the energy and exergy efficiencies of the cooker 
optimization ofdifferent parameters is important. Due to the escape of a large amount of insolation which is not absorbed, and due to the heat loss to the ambient energy efficiencywere found to be very low. As far as exergy is concerned, the exergy efficiency had been found to be lower than that of energy efficiency which is due to the fact that, energy efficiency is based on first law of thermodynamics while the exergy efficiency on second law of thermodynamics which considers all the losses due to irreversibility and entropy generation. Besides, the losses due to absorptance of radiation on the surfaces of the reflector and the cooking pot. The energy efficiency of the SPC was found to be in the range of $6 \%$ to $19 \%$ while the exergy efficiency was found to be below $1 \%$, which is due to the fact as explained above.

Kaushik and Gupta [62] studied the performance analyses of community-size and domestic-size paraboloidal solar cooker based on energy and exergy analyses. The schematic of community-sizeis shown in Figure 4. They showed that the community-size solar cooker has the higher energy and exergy efficiencies and low characteristic boiling time as compared to the domestic-size paraboloidal solar cooker (DSC). In other words, the performance of CSC was found to be better than that of the DSC in all respect.

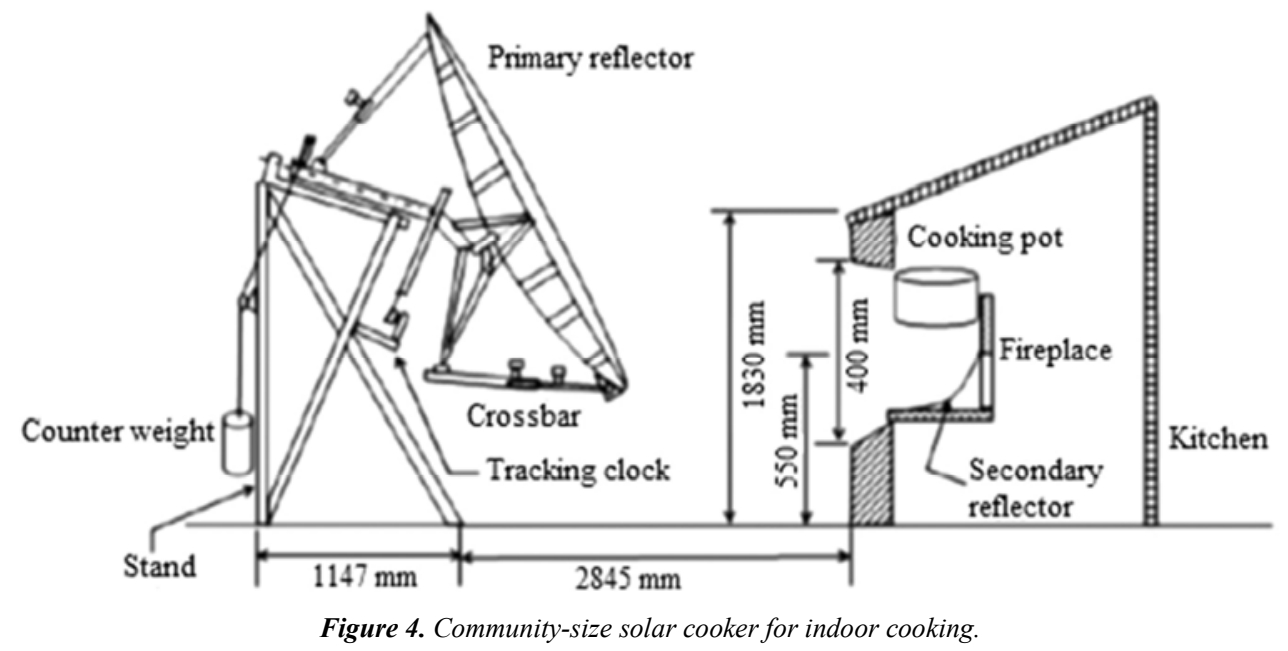

Mawire et al. [63] worked on the thermal energy storage (TES) system of an indirect solar cooker using simulated energy and exergy analysis, an oil-pebblebed was used as the TES material in this research. For the performance analysis ofthe TES system using energy and exergy analyses two different charging methods were used. The constant flow rate for charging the TES system was used in first method however, in the second method, the flow rate was made variable to maintain a constant charging temperature. From their study it was found that the energy stored in constanttemperature charging method had larger than that of constant-flow rate charging method. The energy and exergy rates for the constant- temperature method were found to be slightly lower than that of the constant-flow rate method for lower solar radiation conditions. However, the best results for exergy rates andexergy efficiencies were obtained by using the constant-temperature method at high solar radiation conditions. For both methods, the exergy efficiencies were found tobe smaller than that of the energy efficiencies. Therefore, from the study it was concluded that the constanttemperature method performs better than that of theconstantflow rate method at high solar radiation conditions. While, the performanceof solar cooker at constant-flow rate method was found to be better for low solar radiation conditions.

Mawire et al. [64] also studied the mathematical models for thermal energystorage (TES) system and thermal energy utilization (TEU) system of an indirectsolar cooker to perform the discharging simulations in an indirect solar cooker. Discharging results of the TES system were presented using two different methods. In the first method, the discharge of the TES system was at a constant flow-rate while in the second method, the flow-rate was varied in order to maintain a desired power at a constant inlet temperature. The results of discharging the TES system at a constant flowrate indicated a higher rate of heat utilization which was not found to be beneficial due to the cooking process since, the maximum cooking temperaturecould not be maintained for the duration of the discharging period. On the otherhand, the controlled load power discharging method had a slower initial rate of heat utilization but the maximum cooking temperature was maintained for most of thedischarging process which is the desirable condition for the cooking process.

Kumar et al. [65] investigated a truncated pyramid type solar box cooker (TPSBC) in terms of exergy and energy efficiencies. Two cooking vessels which filled 2Litres of water were used for conducting full load test. During the test period, the booster mirror was covered with black cloth. The water temperature inside the vessels reached $90.6^{\circ} \mathrm{C}$ from $60^{\circ} \mathrm{C}$ in 70 minutes whereas the initial water and ambient temperatures were $43.18^{\circ} \mathrm{C}$ and $33.43^{\circ} \mathrm{C}$, respectively. The maximum and minimum values of insulation were observed as $929 \mathrm{~W} / \mathrm{m}^{2}$ and $376 \mathrm{~W} / \mathrm{m}^{2}$, respectively. The maximum and minimum energy gained from water inside the solar cooker was calculated $20.8 \mathrm{~kJ}$ and $7.5 \mathrm{~kJ}$, respectively. An interesting result in the article was the shift in the output 
exergy peak from that of the output energy peak on the time scale, which is a direct consequence of the decrease in the exergy lost after the water temperature became $>60^{\circ} \mathrm{C}$. In addition exergy analysis of solar box cookers was a practical, comprehensive and realistic tool for solar cookers' performance evaluation. The schematic view of TPSBC is illustrated in Figure 5.

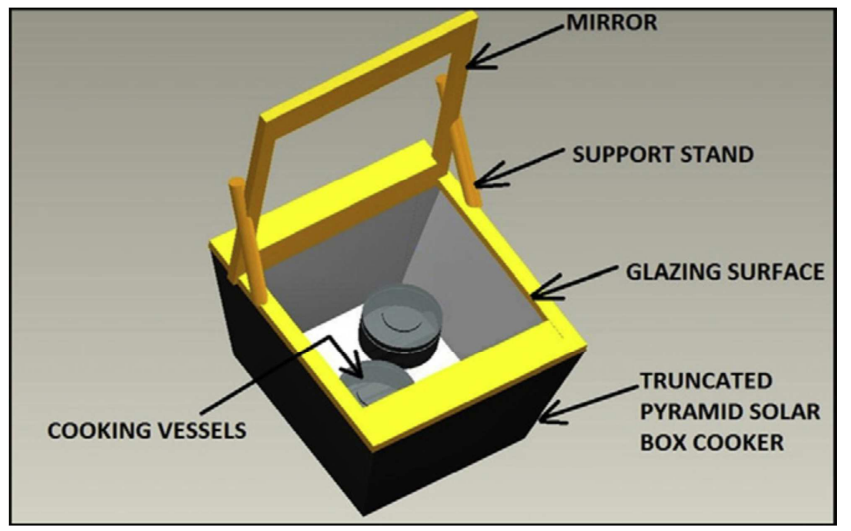

Figure 5. Schematic model of TPSBC with cooking vessels.

Kumar et al. [66] also studied the solar cookers of different geometries and presented an exergy based unified test protocol. In this study, four exergy based parameters viz. peak exergy, quality factor, exergy temperature difference gap product and heat loss coefficient were proposed for solar cookers at different topological design, as their thermal performance indicators. Calculations had been made and graphs between exergy output power and temperature difference wereplotted. It was observed that these parameters resemble a parabolic curve for each design and the peak exergy can be accepted as a measure of devices fuel ratings. They proposed that the quality factor of the solar cooker can be defined as the ratioof the peak exergy power gained to the exergy power lost at an instant of time. It hadalso been found that the exergy power lost is directly proportional to temperature difference irrespective of the topology of the device and the slope of the straight line obtained through curve fitting represents the heat loss coefficient of the cooker. It was also mentioned that the proposed parameters in this study could lead to the development of unified test protocol for solar cookers of different geometries. Pandey et al. [67] evaluated the two different types of solar cookers viz. paraboloid type and box type using exergy analysis. The photographic view of the paraboloid and box type solar cookers has been shown in Figure 6. In this study, the experiments were carried out with 1 and $2 \mathrm{~L}$ of water and $250 \mathrm{~g}$ of rice. The exergetic efficiency with 1 and $2 \mathrm{~L}$ of water in paraboloid type cooker was found to be higher than that of the box type cooker, however, the efficiency with $2 \mathrm{~L}$ water was found to be higher than that of $1 \mathrm{~L}$ of water. The exergetic efficiency with $250 \mathrm{~g}$ of rice for paraboloid type solar cooker was found to be higher than that of the box type cooker. It was also found that the performance of the paraboloid type was better than that of the box type solar cooker.
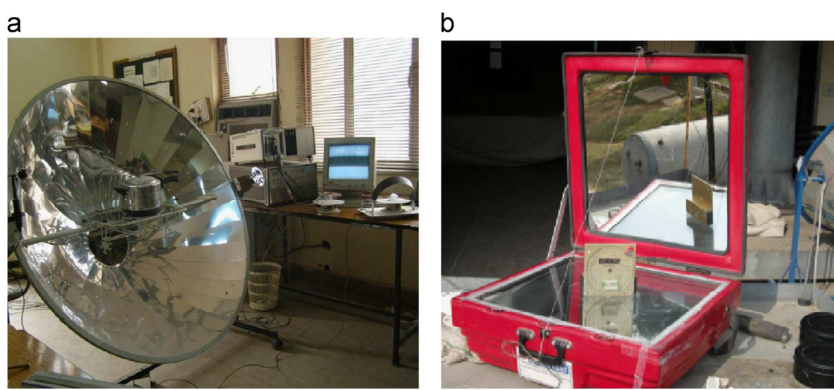

Figure 6. Photographic view of Paraboloid and Boxtype solar cooker (a)Paraboloid solar cooker and (b)boxtype solar cooker.

\section{Effects of the Exergy on Solar Energy System}

Exergy is a tool used to describe the benefits of renewable energy and Technologies. Exergy can be used to assess and improve energy systems, and can help better understand the benefits of utilizing green energy by providing more useful and meaningful information than energy provides. Exergy clearly identifies efficiency improvements and reductions in thermodynamic losses attributable to more sustainable technologies [68]. Exergy can also identify better than energy the environmental benefits and economics of energy technologies. Measures to increase energy efficiency can reduce environmental impact by reducing energy losses [69]. Within the scope of exergy methods, such activities lead to increased exergy efficiency and reduced exergy losses (both waste exergy emissions and internal exergy consumptions). But there are additional ways by which exergy can help understand and reduce environmental impact [70].

\section{Conclusion}

An extensive review on the performance assessment of different solar energy technologies such as solar photovoltaic system, solar thermal system i.e solar air heater, solar water heater and solar cooker based on energy and exergy analysis methods have been done. From the review, the following conclusions have been drawn out:

a. Energy efficiency for all the solar energy systems has been found to be greater than that of exergy efficiency.

b. Exergy analysis method is a very useful tool, especially on performance evaluation of solar energy systems.

c. The exergy efficiency of a solar photovoltaic system was found to range from $0.4 \%$ to $1.25 \%$ [71].

d. Energy and exergy for solar air heater were found to be better with thermal energy storage than those without thermal energy storage.

e. Exergy efficiency for solar water heaters were found to be very low in the range of $3-5 \%$ as obtained by different authors.

f. Performance of paraboloid type solar has been found to be better than that of box type solar cooker. 


\section{References}

[1] International Energy Agency (IEA), 2010, Energy PovertyHow to make access to modern energy universal? http://www.iea.org/weo/docs/weo2010/weo2010_poverty

[2] Bugaje, I. M (2006): Renewable Energy for Sustainable Development in Africa: A Review, Renewable and Sustainable Energy Reviews, volume 10, pp. 603-612.

[3] Holdren, J. P, Morris, G. and Mintzer, I. (1980): 'Environmental aspects of renewable energy sources', Annual Review on Energy, volume 5, pp. 241-291.

[4] World Commission on Environment and Development (WCED), 1987, Our Common Future (The Brundtland Report), Oxford, Oxford University Press, pp. 195.

[5] Oladeji, J. T., (2012): Utilization of Potential of Melon Shells for Pyrolysis as Biomass Fuels, World Rural Observation, volume 4 Issue 2 pp. 60-64.

[6] N. A. Ogie, I. Oghogho and J. Jesumirewhe (2013): Design and Construction of a Solar Water Heater on the Thermsyphon Principle; Journal of Fundamentals of Renewable Energy and Applications, Volume 3, pp. 8.

[7] M. A. Rosen and I. Dincer (2004): A study of industrial steam process heating through exergy analysis, International Journal of Energy Research, Volume 28, pp. 917-930.

[8] Cengel, Y. A. and Boles, M. A. (2010) Thermodynamics: An Engineering Approach, 7th edition, McGraw-Hill, New York.

[9] Rosen, M. A. and Dincer, I. (1999) 'Thermal storage and exergy analysis: the impact of stratification', Transactions on the CSME (IB), Volume 23, pp.173-186.

[10] Pandey AK. Exergy analysis and exergoeconomic evaluation of renewable energy conversion systems. Ph.D. Thesis. School of Energy Management, Shri Mata Vaishno Devi University, Katra; India; 2013.

[11] Sahin A. D., Dincer I., Rosen M. A. (2007). Thermodynamic analysis of solar photovoltaic cell systems. Solar Energy Material and Solar Cells, volume 91, pp: 153-159.

[12] Hepbasli A. (2008). A key review on exergetic analysis and assessment of renewable energy resources for a sustainable future. Renewable and Sustainable Review, volume 12, pp: 593-661.

[13] Fujisawa T., Tani T. (1997). Annual exergy evaluation on photovoltaic-thermal hybrid collector. Solar Energy Materials and Solar Cells, volume 47, pp: 135-148.

[14] Saitoh H., Hamada Y., Kubota H., Nakamura M., Ochifuji K., Yokoyama S. (2003). Field experiments and analyses on a hybrid solar collector. Applied Thermal Engineering, volume 23, pp: 2089-2105.

[15] Joshi A. S., Dincer I., Reddy B. V. (2009). Thermodynamic assessment of photovoltaic systems. Solar Energy, volume 83, pp: 1139-1149.

[16] Sarhaddi F., Farahat S., Ajam H., Behzadmehr A. (2010). Exergetic performance assessment of a solar photovoltaic thermal (PV/T) air collector. Energy and Buildings, volume 42, pp: 2184-2199.
[17] Hosseini M, Dincer I, Rosen MA. Hybrid solar fuel cell combined heat and power systems for residential applications: energy and exergy analyses. Journal of Power Sources 2013; 221:372-380.

[18] Tiwari G. N., Mishra R. K., Solanki S. C. (2011). Photovoltaic modules and their applications: A review on thermal modeling. Applied Energy, volume 88, pp: 2287-2304.

[19] Joshi A. S., Dincer I., Reddy B. V. (2009). Performance analysis of photovoltaic systems: A review. Renewable and Sustainable Energy Reviews, volume 13, pp: 1884-1897.

[20] Vats K., Tiwari G. N. (2012). Energy and exergy analysis of a building integrated semitransparent photovoltaic thermal (BISPVT) system. Applied Energy (Article in press).

[21] Ozturk HH, Demirel Y. Exergy-based performance analysis of packed-bed solar airheaters. International Journal of Energy Research 2004;28:423-32.

[22] Sukhatme SP. Solar energy. New York: McGraw-Hill; 1993.

[23] Pangavhane D. R., Sawhney R. L. (2002). Review of research and development work on solar driers for grape drying. Energy Conversion and Management, volume 43, pp. 45-61.

[24] Midilli A. (2001). Determination of pistachio drying behavior and conditions in a solar drying system. International Journal of Energy Research, Volume 25, pp.715-725.

[25] Shanmugam V., Natarajan E. (2007). Experimental study of regenerative desiccant integrated solar dryer with and without reflective mirror. Applied Thermal Engineering, Volume 27, pp. 1543-1551.

[26] Kurtbas I., Durmus A. (2004). Efficiency and exergy analysis of a new solar airheater. Renewable Energy, Volume 29, pp:1489-1501.

[27] Luminosu I., Fara L. (2005). Determination of the optimal operation mode of aflat solar collector by exergetic analysis and numerical simulation. Energy, Volume 30, pp:731-747.

[28] Torres-Reyes J. J., González N., Zaleta-Aguilar A., Gortari J. G. C. (2003). Optimal process of solar to thermal energy conversion and design ofirreversible flat plate solar collectors. Energy, Volume 28, pp: 99-113.

[29] Bakos C., Ioannidis I., Tsagas N. F., Seftelis I. (2001). Design optimization andconversion efficiency determination of a linefocus-parabolic-trough solarcollector. Applied Energy, Volume 68, pp: $43-50$.

[30] Kaushik S. C., Singhal M. K., Tyagi S. K. (2001). Solar collector technologies forpower generation and space air conditioning applications - a state of the artinternal report. Centre for Energy Studies; Indian Institute of Technology; Delhi: India.

[31] Tyagi S. K., Wang S. W., Kaushik S. C., Singhal M. K., and Park S. R. (2007). Exergy analysis and parametric study of concentrating type solar collectors. International Journal of Thermal Sciences, Volume 46, pp: 1304-1310.

[32] Enibe S. O. (2002). Performance of a natural circulation solar air heating system with phase change material energy storage. Renewable Energy, Volume 27, pp: 69-86.

[33] Ajam H., Farahat S., Sarhaddi F. (2005). Exergetic Optimization of Solar Air Heaters and Comparison with Energy Analysis. International Journal of Thermodynamics, Volume 8, Issue 4, pp: 183-190. 
[34] Ozturk H. H., Demirel Y. (2004). Exergy-based performance analysis of packed-bed solar air heaters. International Journal of Energy Research, Volume 28, pp: 423-432.

[35] MacPhee D., Dincer I. (2009). Thermal modelling of a packed bed thermalenergy storage system during charging. Applied Thermal Engineering, Volume 29, pp: 695-705.

[36] Kurtbas I., Turgut E. (2006). Experimental Investigation of Solar Air Heaterwith Free and Fixed Fins: Efficiency and Exergy Loss. International Journal of Science and Technology, Volume 1, Issue 1, pp: 75-82.

[37] Esen H. (2008). Experimental energy and exergy analysis of a double-flow solar air heater having different obstacles on absorber plates. Building and Environment, Volume 43, pp: $1046-1054$

[38] Ucar A., Inall M. (2006). Thermal and exergy analysis of solar air collectorswith passive augmentation techniques. International Communications in Heatand Mass Transfer volume 33, pp: 1281-1290.

[39] Koca A., Oztop H. F., Koyun T., Varol Y. (2008). Energy and exergy analysisof a latent heat storage system with phase change material for a solarcollector. Renewable Energy, volume 33, pp:567-574.

[40] Gupta M. K., Kaushik S. C. (2009). Performance evaluation of solar air heaterfor various artificial roughness geometries based on energy, effective andexergy efficiencies. Renewable Energy, volume 34, pp:465-476.

[41] Ozgen F., Esen M., Esen H. (2009). Experimental investigation of thermalperformance of a double-flow solar air heater having aluminium cans. Renewable Energy, volume 34, pp:2391-2398.

[42] Farahat S., Sarhaddi F., Ajam H. (2009). Exergetic optimization of flat platesolar collectors. Renewable Energy, volume 34, pp: 1169-1174.

[43] Akbulut A., Durmuş A. (2010). Energy and exergy analyses of thin layerdrying of mulberry in a forced solar dryer. Energy, volume 35, pp: 1754-1763.

[44] Akpinar E. K., Kocyigit F. (2010). Energy and exergy analysis of a new flatplatesolar air heater having different obstacles on absorber plates. Applied Energy, volume 87, pp:3438-3450.

[45] Alta D., Bilgili E., Ertekin C., Yaldiz O. (2010). Experimental investigation ofthree different solar air heaters: Energy and exergy analyses. Applied Energy, volume 87, pp:2953-2973.

[46] Prommas R., Rattanadecho P., Cholaseuk D. (2010). Energy and exergyanalyses in drying process of porous media using hot air. InternationalCommunications in Heat and Mass Transfer, volume 37, pp: 372-378.

[47] Panwar N. L., Kaushik S. C., Kothari S. (2012). A review on energy and exergyanalysis of solar dying systems. Renewable and Sustainable Energy Reviews, volume 16, pp: 2812-2819.

[48] Saidur R., BoroumandJazi G., Mekhlif S., Jameel M. (2012). Exergy analysisof solar energy applications. Renewable and Sustainable Energy Reviews, volume 16, pp: 350-356.

[49] Ceylan I. (2012). Energy and exergy analyses of a temperature controlled solar water heater. Energy and Buildings, volume 47, pp: $630-635$.

[50] Xiaowu W., Ben H. (2005). Exergy analysis of domestic-scale solar water heaters. Renewable and Sustainable Energy Reviews, volume 9, pp: 638-645.

[51] Gunerhan H., Hepbasli A. (2007). Exergetic modeling and performanceevaluation of solar water heating systems for building applications. Energyand Buildings, volume 39, pp: 509-516.

[52] Hayek M., Assaf J., Lteif W. (2011). Experimental Investigation of thePerformance of Evacuated- Tube Solar Collectors under EasternMediterranean Climatic Conditions. Energy Procedia, volume 6, pp: 618-626.

[53] Ayompe L. M., Duffy A., Mc Keever M., Conlon M., McCormack S. J. (2011). Comparative field performance study of flat plate and heat pipe evacuatedtube collectors (ETCs) for domestic water heating systems in a temperateclimate. Energy, volume 36, pp:3370-3378.

[54] Gang P., Guiqiang L., Xi Z., Jie J., Yuehong S. (2012). Experimental studyand exergetic analysis of a CPC-type solar water heater system using highertemperaturecirculation in winter. Solar Energy, volume 86, pp: 1280-1286.

[55] Mullick S. C., Kandpal T. C., Saxena A. K. (1987). Thermal test procedure for box-type solar cookers. Solar Energy, volume 39, issue 4, pp: 353.

[56] El-Sebaii A. A. (1997). Thermal performance of a box type solar cooker with outer-inner reflectors. Energy, volume 22, pp: 969-978.

[57] Ozturk H. H. (2004). Second law analysis for solar cookers. InternationalJournal of Green Energy, volume 1, issue 2, pp: 227-239.

[58] Petela R. (2005). Exergy analysis of the solar cylindricalparabolic cooker. Solar Energy, volume 79, pp:221-233.

[59] Nahar N. M. (1998). Design, development and testing of a novel non-trackingsolar cooker. International Journal of Energy Research, volume 22, pp:1191-1198.

[60] Gaur A., Singh O. P., Singh S. K., Pandey G. N. (1999). Performance study ofsolar cooker with modified utensil. Renewable Energy, volume 18, pp:121-129.

[61] Buddhi D., Sharma S. D., Sawhney R. L. (1999). Performance test of a boxtype solar cooker: Effect of load on second figure of merit. InternationalJournal of Energy Research, volume 23, pp: 827-830.

[62] Kaushik S. C., Gupta M. K. (2008). Energy and exergy efficiency comparison ofcommunity-size and domestic-size paraboloidal solar cooker performance. Energy for Sustainable Development, volume XII, issue 3, pp: 60-64.

[63] Mawire A., McPherson M., van den Heetkamp R. R. J. (2008). Simulatedenergy and exergy analysis of the charging of an oil-pebble bed thermal energy storage system for a solar cooker. Solar Energy Materials and Solar Cells, volume 92, pp: $1668-1676$.

[64] Mawire A., McPherson M., Van den Heetkamp R. R. J. (2010). Dischargingsimulations of a thermal energy storage (TES) system for an indirect solar cooker. Solar Energy Materials and Solar Cells, volume 94, pp:1100-1106.

[65] Kumar N., Vishwanath G., Gupta A. (2011). An exergy based test protocol fortruncated pyramid type solar box cooker. Energy, volume 36, pp: 5710-5715. 
[66] Kumar N., Vishwanath G., Gupta A. (2012). An exergy based unified testprotocol for solar cookers of different geometries. Renewable Energy, volume 44, pp:457-462.

[67] Pandey AK, Tyagi VV, Park SR, Tyagi SK. Comparative experimental study of solar cookers using exergy analysis. Journal of Thermal Analysis and Calorimetry 2012;109:42531 .

[68] F. bayrak, N. Abu-Hamdeh, K. A. Alnefaic and H. F. Oztop (2017): A Review on Exergy Analysis of Solar Electricity Production, Renewable and Sustainable Energy Reviews; volume 74, pp: 755-770.
[69] K. Kaygusuz and S. Bilgen (2009): Thermodynamic Aspects of Renewable and Sustainable Development, Journal of Energy Sources, Part A: Recovery, Utilization and Environmental Effects, volume 31, issue 4.

[70] Rosen M. A., Dincer I. and Kanoglu M. (2008): Role of exergy in increasing efficiency and sustainability and reducing environmental impact. Energy Policy; volume 36, pp: 128-37.

[71] Ozturk H. H. (2004): Experimental determination of energy and exergy efficiency of the solar parabolic-cooker. Solar energy, volume 77, pp: 67-71. 